\title{
JNPH
}

Volume 6 No. 2 (Oktober 2018)

(C) The Author(s) 2018

\section{PENGARUH BUAH BIT (BETA VULGARIS) TERHADAP INDEK ERITROSIT PADA REMAJA PUTRI DENGAN ANEMIA}

\author{
EFFECT OF BETA VULGARIS ON INDEX ERYTHROCYTE \\ IN WOMEN ADOLESCENT WITH ANEMIA
}

\author{
KARTIKA IKAWATI ${ }^{1}$, ROKHANA ${ }^{2}$ \\ ${ }^{1}$ DOSEN DI AKADEMI ANALIS KESEHATAN 17 AGUSTUS 1945 SEMARANG \\ ${ }^{2}$ DOSEN DI AKADEMI ANALIS FARMASI 17 AGUSTUS 1945 SEMARANG \\ JL. JENDRAL SUDIRMAN 350 SEMARANG. TELP/FEK/SUREL (024)7608694/ \\ (024)7625060/WWW.ANALIS17SMG.COM \\ E-mail : kartika.aisha@yahoo.com
}

\begin{abstract}
ABSTRAK
Prevalensi Anemia pada remaja putri di Indonesia masih tinggi dan umumnya disebabkan defisiensi zat gizi mikro. Buah bit banyak mengandung zat gizi mikro yang dibutuhkan untuk perbaikan anemia. Indek Eritrosit digunakan untuk mengetahui derajad dan jenis anemia berdasarkan morfologi. Penelitian ini bertujuan untuk mengetahui pengaruh konsumsi buah bit terhadap indek eritrosit pada remaja putri dengan anemia. Jenis penelitian yang digunakan eksperimen dengan rancangan one group pretest posttest. Sampel penelitian 30 orang dari populasi mahasiswi AAK 17 Agustus 1945 Semarang dengan teknik sampling quota. Obyek penelitian digunakan darah vena EDTA. Asupan buah bit sebanyak 200 gr yang dikonsumsi dalam bentuk sari buah bit $250 \mathrm{ml} /$ hari selama 7 hari. Nilai Indek eritrosit diperhitungkan dari kadar $\mathrm{Hb}$, jumlah eritrosit dan nilai hematokrit yang diperiksa dengan alat hematology analyzer. Data kemudian dianalisis dengan uji beda Paired T-test dan Wilcoxon test. Rata-rata kadar Hemogobin meningkat sebesar 1,3 g/dl (12\%), hematokrit meningkat sebesar $4 \mathrm{vol} \%$ (13\%), jumlah eritrosit meningkat sebanyak $310.329 \mathrm{sel} / \mu 1$ (8,4\%). Untuk Indek Eritrosit terjadi peningkatan nilai rata-rata MCV sebesar 3fl (3,5\%), nilai $\mathrm{MCH}$ meningkat $1 \mathrm{pg}(3 \%)$ dan nilai MCHC meningkat 1 point atau 3\%. Hasil uji beda didapatkan nilai $\mathrm{P}<0.05$. Terdapat peningkatan yang bermakna terhadap nilai Indek Eritrosit setelah mengonsumsi buah bit. Konsumsi buah bit berpengaruh terhadap peningkatan nilai indek eritrosit remaja putri dengan anemia.
\end{abstract}

Kata kunci : Buah bit, anemia, indek eritrosit

\begin{abstract}
Prevalence of anemia in young women in Indonesia is still high and is generally caused by micronutrient deficiency. Beta vulgaris contain of micronutrients needed to improve anemia. Index Erythrocyte is used toseverityand type of anemia based on morphology. This study aims to determine the effect of consumption of Beta vulgaris on Index Erythrocyte in women adolescent with anemia. This type of research was used experimentally with the design of one
\end{abstract}


group pretest posttest. The research sample was 30 people from the population of AAK 17 August 1945 Semarang population with a quota sampling technique. The research object used EDTA venous blood. A total 200 grams of beetroot intake is consumed in the form of $250 \mathrm{ml}$ beet juice every day for 7 days. The Index Erythrocyte value was calculated from Hemoglobin levels, erythrocyte counts and hematocrit values examined by a hematology analyzer. The data was then analyzed by different test Paired T-test and Wilcoxon test. The average hemogobin level increased by $1.3 \mathrm{~g} / \mathrm{dl}(12 \%)$, hematocrit increased by 4 vol\% (13\%), the erythrocytes increased by 310.329 cells / $\mu 1(8.4 \%)$. The parameters Index Erythrocyte there was an increase in mean MCV value of $3 \mathrm{fl}(3.5 \%)$, the $\mathrm{MCH}$ value increased by $1 \mathrm{pg}(3 \%)$ and the $\mathrm{MCHC}$ value increased by 1 point or $3 \%$. Different test results obtained from $\mathrm{P}<0.05$. There was a significant increase in the value of the Index Erythrocyte after consuming the Beta vulgaris. Consumption of Beta vulgaris affects the increase in Index Erythrocyte in women adolescent with anemia.

\section{Keywords: Beta vulgaris, anemia, Index Erythrocyte}

\section{PENDAHULUAN}

Anemia merupakan kondisi menurunnya kadar hemoglobin $(\mathrm{Hb})$, jumlah eritrosit, kadar hematocrit/Packed cells volume (PCV) dan nilai Indek Eritrosist diluar nilai rujukan. Anemia timbul jika sel darah merah berukuran terlalu kecil (mikrositik) atau terlalu besar (makrositik). Anemia juga berkaitan dengan gangguan pembentukan hemoglobin sehingga konsentrasi hemoglobin tinggi (hiperkomik) atau rendah (hipokromik) (Price S,2006). Seseorang dikatakan anemia jika kadar hemoglobin $(\mathrm{Hb})<12 \mathrm{rg} / \mathrm{dL}$ (untuk wanita dewasa) dan $<13 \mathrm{gr} / \mathrm{dL}$ ( untuk lakilaki dewasa) (Depkes RI, 2005). Anemia menjadi permasalahan kesehatan terutama di negara berkembang seperti Indonesia.Anemia yang umum terjadi di dunia adalah anemia defisiensi zat gizi mikro seperti zat besi dan banyak diderita oleh remaja. (WHO, 2006).

Indek Eritrosit merupakan suatu parameter pemeriksaan hematologi yang digunakan untuk megetahui jenis anemia berdasarkan morfologi. Pemeriksaan indeks eritrosit terdiri dari pemeriksaan Mean Corpuscular Value (MCV), Mean Corpuscular Hemoglobin (MCH), dan Mean Corpuscular Hemoglobin Concertration (MCHC) (Suhartati \& Alwi, 2015). Nilai Indek Eritrosit diperoleh dari perhitungan kadar hemoglobin, jumlah eritrosit dan hematocrit. Nilai MCV menunjukkan volume eritrosit rata-rata, sedangkan nilai $\mathrm{MCH}$ dan MCHC menunjukkan kadar hemoglobin eritrosit rata-rata (Gandasubrata S, 2010). Nilai rujukan MCV (82-92 fl), MCH (27-31 pg) dan MCHC (32-36 \%) (Sudoyo AW, 2009). Seseorang dengan anemia mikrositik hipokromik akan mengalami penurunan nilai $\mathrm{MCV}, \mathrm{MCH}$ dan $\mathrm{MCHC}$, sebaliknya jika seseorang menderia anemia makrositik maka akan mengalami kenaikan nilai Indek Eritrosit. Nilai MCHC baru akan turun jika anemia telah berlangsung lama atau berat. Derajat perubahan kadar Indeks Eritrosit ini berhubungan dengan berat dan lama terjadinya anemia (Suega et al, 2007).

Menurut data hasil Riskesdas tahun (2013), prevalensi anemia diIndonesia yaitu $21,7 \%$. Prevalensi anemia pada perempuan lebih tinggi dibanding laki-laki. Prevalensi anemia pada laki-laki $18,4 \%$ dan perempuan 23,9\%. Sedangkan berdasarkan kelompok umur, prevalensi anemia pada kelompok umur 5-14 tahun sebesar26,4\% dan pada remaja umur 15-21 tahun sebesar 18,4 \% (Kemenkes RI, 2013). DataSurvei Kesehatan Rumah Tangga (2012), menyatakan bahwaprevalensi anemia pada balita sebesar 40,5\%, ibu hamil sebesar 50,5\% dan ibunifas sebesar 45,1\%. Anemia menjadi masalah kesehatan jika melebihi abang batas $\geq 20 \%$. (Direktur Bina Gizi/RAPGM, 2014).

Wanita mempunyai risiko terkena anemia palingtinggi terutama pada remaja 
putri (Kemenkes RI, 2013). Kadar hemoglobin rendah banyak dialami pada kelompok usia remaja khususnya remaja putri karena beberapa faktor. Pada usia ini kebutuhan zat besi meningkat. Pematangan seksual pada remaja menyebabkan kebutuhan zat besi meningkat. Kebutuhan zat besi remaja putri lebih tinggi dibanding remaja laki-laki, karena dibutuhkan untuk mengganti zat besi yang hilang pada saat menstruasi (Hallberg, B.1994). Dampak anemia pada remaja putri menyebabkan terhambatnya pertumbuhan, rentan infeksi, mudah letih, dan meurunnya semangat belajar. (Badriah, 2014).

Penanganan terhadap anemia dapat dilakukan dengan 2 cara yaitu secara farmakologi dan non farmakologi. Penangan secara farmakologi dengan menggunakan tablet (Fe), tetapi cara ini sering tidak disukai karena sering menimbulkan mual dan muntah karena bau besi. Oleh karena itu diperlukan terobosan sehat dan aman dengan megkonsumsi buah bit (Beta vulgaris). Buah bit kaya akan zat gizi yang dibutuhkan untuk pembentukan dan pematangan sel darah merah.

Buah bit yang dikenal dengan akar bit maupun bit merah ini merupakan salah satu jenis tanaman dari kelompok Amaranthaceae.Tanaman ini tergolong umbiumbian yang banyak ditemukan di wilayah Amerika Utara maupun Inggris. Di Indonesia tanaman ini tumbuh di daerah dengan tanah yang subur, gembur $\mathrm{pH}$ 6-7 dengan curah hujan yang cukup dan ketinggian lebih dari 100 meter. (Laksmi, 2004).

Umbi bit mengandung vitamin, karbohidrat, protein, dan lemak yang berguna untuk kesehatan tubuh. (Puslitbangkes.2013). Mineral lainnya juga terkandung dalam umbi bit seperti Iron ( $\mathrm{Fe})$, Natrium (Na), Zink (Zn), Calsium (Ca), Potassium (K), Magnesium (Mg) dan Phosphorus (P). Bit merah mengandug vit $\mathrm{C} 10,2 \%$ dan asam folat $34 \%$ yang berfungsi untuk menumbuhkan dan mengganti sel-sel yang rusak (USDA, 2014).

Menurut penelitian Suryandari AE,
(2015) tentang "Perbandingan kenaikkan kadar $\mathrm{Hb}$ pada ibu hamil yang diberi $\mathrm{Fe}$ dengan Fe dan buah bit di wilayah kerja Puskesmas Purwokerto Selatan" diketahui bahwa jus buah bit $500 \mathrm{ml}$ selama 7 hari dapat meningkatkan kadar hemoglobin antara 0,6 $0,8 \mathrm{gr} / \mathrm{dl}$. Hasil penelitian Indumathi $\mathrm{T}$, terhadap manfaat buah bit yang diberikan pada hewan coba, mendapatkan jumlah sel darah merah lebih tinggi pada pemberian 400 $\mathrm{mg} / \mathrm{kgBB}$ ekstrak bit dibandingkan pemberian 200 dan 100 mg/kgBB. Hasil pemeriksaanMCV, $\mathrm{MCH}$ dan $\mathrm{MCHC}$ juga menunjukkan hasil yang sejalan dengan peningkatan dosis ekstrak yang diberikan. (Indumathi T, 2015).

Penelitian pengaruh buah bit terhadap perbaikan nilai indek eritrosit pada remaja putri denagn anemia belum pernah dilakukan, Oleh karena itu perlu dilakukan penelitian dengan judul "Pengaruh Konsumsi Buat Bit terhadap Indek Eritrosit pada Remaja Putri dengan Anemia" Penelitian ini bermanfaat untuk mengurangi kejadian anemia pada remaja putri dengan cara non farmakologi dengan menggunakan buah bit.

\section{METODE PENELITIAN}

Jenis penelitian ini adalah eksperimen dengan desain one group pre test post tes, yaitu penelitian yang dilakukan pada satu kelompok yang diukur sebelum dan setelah perlakuan. Populasi penelitian adalah mahasiswi AAK 17 Agustus 1945 Semarang yang memenuhi kreteria inklusi yaitu; responden remaja putri (usia 17-25 tahun), bersedia menjadi subyek penelitian, menderita anemia ringan (kadar $\mathrm{Hb} \quad 8-10$ $\mathrm{gr} / \mathrm{dl}$ ) dan mempunyai tekanan darah normal. Kriteria eksklusi ; responden tidak mengikuti proses penelitian sampai selesai, mengunsumsi suplemen zat besi dan mengalami menstruasi selama perlakuan. Tehnik sampling dilakukan dengan cara Quota sampai diperoleh 30 sampel.Asupan buah bit sebanyak 200 gr yang dikonsumsi dalam bentuk sari buah bit dengan volume $250 \mathrm{ml} /$ hari selama 7 hari. Nilai Indek 
Eritrosit diperhitungkan dari kadar $\mathrm{Hb}$, jumlah eritrosit dan nilai hematokrit. Pemeriksaan parameter indek eritrosit dengan menggunakan alat hematology analyzer. Nilai MCV dihitung dengan rumus nilai $\mathrm{PCV} /$ jumlah eritrosit dikali 10. Nilai $\mathrm{MCH}$ dihitung dengan rumus $\mathrm{HB} / \mathrm{jumlah}$ eritrosit dikali 10, sedangkan nilai $\mathrm{MCHC}$ dihitung dengan rumus $\mathrm{HB} / \mathrm{PCV}$ dikali 100. Data kemudian dianalisis dengan uji beda Paired T-test dengan bantuan SPSS versi 25 .

\section{HASIL PENELITIAN}

Berdasarkan pemeriksaan nilai indeks eritrosit sebelum dan sesudah mengonsumsi sari buah bit sebanyak $250 \mathrm{ml}$ selama 7 hari terhadap 30 mahasiswi AAK 17 Agustus 1945 Semarang didapatkan hasil sebagai berikut:

Tabel 1. Nilai Indeks Eritrosit Sebelum dan Sesudah Mengonsumsi Buah bit

\begin{tabular}{|c|c|c|c|c|c|c|}
\hline & $\begin{array}{r}\mathrm{Se} \\
\text { Konst }\end{array}$ & $\begin{array}{l}\text { belum } \\
\text { amsi Buah }\end{array}$ & & & & \\
\hline Kadar & & Bit & Setela & Konsu & nsi Bu & h Bit \\
\hline & Min & Mak & $\begin{array}{l}\text { Rata- } \\
\text { Rata }\end{array}$ & Min & Mak & $\begin{array}{l}\text { Rata- } \\
\text { Rata }\end{array}$ \\
\hline $\begin{array}{c}\mathrm{Hb} \\
(\mathrm{g} / \mathrm{dl})\end{array}$ & 8,9 & 11,8 & 10,6 & 9,8 & 12,9 & 11,9 \\
\hline $\begin{array}{c}\text { Hemat } \\
\text { okrit } \\
(\%)\end{array}$ & 27 & 34 & 31 & 31 & 38 & 35 \\
\hline $\begin{array}{l}\text { Jumlah } \\
\text { Eritrosi }\end{array}$ & 3.434. & & 3.711 .9 & 3.513. & 4.826 . & 4.022. \\
\hline $\mathrm{t}(\mathrm{ul})$ & 700 & 4.159 .000 & 9 & 00 & 900 & 248 \\
\hline $\begin{array}{c}\mathrm{MCV} \\
(\mathrm{fl})\end{array}$ & 79 & 90 & 85 & 75 & 93 & 88 \\
\hline $\begin{array}{c}\mathrm{MCH} \\
(\mathrm{pg})\end{array}$ & 25 & 31 & 29 & 27 & 31 & 30 \\
\hline $\begin{array}{c}\mathrm{MCHC} \\
(\%)\end{array}$ & 30 & 35 & 33 & 31 & 36 & 34 \\
\hline
\end{tabular}

Dari tabel 1 diketahui bahwa setelah mengonsumsi buah bit terjadi peningkatan rata-rata kadar $\mathrm{Hb}$, hematokrit, jumlah eritrosit dan Indek Eritrosit. Rata-rata kadar Hemogobin meningkat sebesar $1,3 \mathrm{~g} / \mathrm{dl}$ atau $12 \%$. Rata-rata kadar hematokrit meningkat sebesar 4 vol $\%$ atau $13 \%$, sedangkan rata-rata jumlah eritrosit meningkat sebanyak 310.329 sel $/ \mu \mathrm{l}(8,4 \%)$. Untuk Indek Eritrosit terjadi peningkatan nilai rata-rata $\mathrm{MCV}$ sebesar $3 \mathrm{fl}$ atau 3,5\%, nilai $\mathrm{MCH}$ meningkat 1 pg (3\%) dan nilai $\mathrm{MCHC}$ meningkat 1 point atau 3\%

Data nilai indek eritrosit yang diperoleh kemudian diolah normalitas datanya dengan menggunakan uji Shapiro Wilk .Hasil uji normaliatas data dan uji perbedaan dapat diketahui dari tabel 2 berikut ini :

\section{Tabel 2. Hasil Uji Normalitas dan Uji Beda Paired T-Test dan Wilcoxon}

\begin{tabular}{ccc}
\hline & Uji Normalitas & Uji Statistik \\
\cline { 2 - 3 } & ShapiroWik & \\
\cline { 2 - 3 } & Sig. & Sig. \\
\hline $\begin{array}{c}\text { MCV sebelum } \\
\text { (fl) }\end{array}$ & 0,326 & 0,000 \\
\hline MCV sesudah & 0,005 & \\
\hline $\begin{array}{c}\text { MCH sebelum } \\
\text { (pg) }\end{array}$ & 0,337 & 0,000 \\
\hline MCH ssudah & 0,080 & 0,020 \\
\hline $\begin{array}{c}\text { MCHC } \\
\text { sebelum (\%) }\end{array}$ & 0,030 & \\
\hline $\begin{array}{c}\text { MCHC } \\
\text { sesudah }\end{array}$ & 0,263 & \\
\hline
\end{tabular}

Uji normalitas dengan uji Saphiro Wilkdidapatkan bahwa nilai $\mathrm{MCH}$ berdistribusi normal sedangkan $\mathrm{MCV}$ dan MCHC berdistribusi tidak normal. Hasil uji beda terhadap nilai $\mathrm{MCH}$ sebelum dan sesudah mengonsumsi buah bit dengan menggunakan uji Paired $T$ Test dan didapatkan hasil $P<0,05$. Uji beda MCV dan MCHC menggunakan uji Wilcoxon karena berdistribusi tidak normal. Hasil uji beda $\mathrm{MCH}$ dan MCHC didapatkan nilai $P<0.05$.

Hasil ini sejalan dengan penelitian Stepana W (2017), yang mendapatkan hasil rata-rata kadar $\mathrm{Hb}$ ibu hamil pada kelompok eksperimen sebelum pemberian jus buah bit 9,50 gr/dL dan 9,18 g/dL pada kelompok kontrol. Setelah pemberian jus buah bit terjadi peningkatan kadar $\mathrm{Hb}$, dimana pada kelompok eksperimen kadar $\mathrm{Hb}$ 11,27gr/dL dan pada kelompok kontrol 9,22 gr/dL hasil uji statistik mendapatkan adanya peningkatan yang bermakna dengan $\mathrm{P}<0,05$.

Setelah pemberian jus buah bit 
sebanyak 200 gr dalam betuk jus dengan volume $250 \mathrm{ml}$ selama 7 hari didapatkan adanya peningkatan indek iritrosit. Salah satu penyebab meningkatnya kadar indeks eritrosit setelah megonsumsi sari buah bit adalah karena kandungan zat gizi seperti zat besi, vitamin C, asam amino (triptofan, lisin), kalsium, fosfor, belerang, vitamin A, vitamin B1,dan betasianin sebagai antioksidan (Helmi et al. 2013).

Besi, asam folat, vitamin B12, protein, piridoksin, vitamin $\mathrm{C}$, tembaga dan vitamin $\mathrm{E}$ mengambil peran penting dalam sumsum tulang. Asam folat dan B12 berperan dalam metabolisme seluler dan dibutuhkan dalam perkembangan normal eritrosit di sumsum tulang. Zat besi dengan vitamin $\mathrm{C}$ membentuk askorbat besi kompleks yang larut dan mudah diserap oleh organ-organ pada tubuh manusia. Pengubahan zat besi non-heme dalam bentuk senyawa anorganik yaitu Ferri $\left(\mathrm{fe}^{3^{+}}\right)$menjadi ferro $\left(\mathrm{fe}^{2+}\right)$ akan semakin besar bila $\mathrm{pH}$ di dalam labung semakin asam. (Hallberg, 1994 ; Zhu, 2006; Thankachan, 2008).

Buah bit mengandung vitamin $\mathrm{C}$ dua sampai empat kali lipat disbanding jeruk. (Sulistyowati, 2015). Keasaman di lambung yang terjadi karena vitamin $\mathrm{C}$ dapat membantu meningkatkan penyerapan zat besi sebanyak 30\% (Sianturi C, 2012). Vitamin C akan membantu meningkatkan absorbs zat besi non heme hingga empat kali lipat. Hasil penelitian terhadap 56 pasien hemodialisa, kemudian dilakukan evaluasi mengenai hubungan hemoglobin dengan kadar vitamin $\mathrm{C}$ plasma. Total kadar hemoglobin berkorelasi positif terhadap kadar vitamin $\mathrm{C}$ plasma. Hasil Penelitian mengatakan bahwa vitamin $\mathrm{C}$ dapat meningkatkan produksi sel darah merah dengan cara memobilisasi simbapan zat besi di jaringan dalm bentuk hemosiderin. Vitamin $\mathrm{C}$ juga membantu melepaskan besi dari transferrin dalam plasma agar dapat bergabi=ung ke dalam ferritin jaringan. Kandungan protein dalam buah bit yang terdiri dari asam amino bersama denagn vitamin $\mathrm{C}$ akan membantu proses reduksi feri $(\mathrm{Fe}+++)$ menjadi fero $(\mathrm{Fe}++)$ agar mudah diserap. (Sianturi $\mathrm{C}$,
2012).

Peningkatan parameter Indek eritrosit yang berdampak pada peniningkatan nilai Indek eritrosit, tidak terlepas dari peran pigmen betasianin yang terdapat dalam buah bit. Betasianin dari buah bit telah diketahui memiliki efek antiradikal dan aktivitas antioksidan yang tinggi (Mastuti, 2010). Menurut Mareno, et. Al.,(2008). Pigmen betasianin buah bit banyak dimanfaatkan karena kegunaannya sebagai radical savenging sebagai perlindungan terhadap gangguan akibat stres oksidatif, membersihkan racun, memproduksi sel, mengobati infeksi, anti inflamasi dan anti kanker. Antioksidan akan menghambat terjadinya reaksi berantai dari pembentukan radikal bebas yang dapat menimbulkan stress oksidatif. (Setiawan MAW, 2015)

Kandungan pigmen dalam buah bit merupakan Senyawa antioksidan berpengaruh terhadap ketahanan dinding eritrosit, Membran eritrosit merupakan salah satu membran sel yang rentan terhadap serangan radikal bebas. Apabila radikal bebas menyerang membran eritrosit, maka fluiditas membran sel akan terganggu yang dapat menyebabkan lisis bahkan kematian sel sehingga akan terjadi perubahan pada jumlah eritrosit dan kadar hemoglobin. Hal ini yang mengakibatkan terjadinya penurunan jumlah eritrosit. Oleh karena itu dengan mengonsumsi buah bit yang mengandung flavonoid dapat mempengaruhi peningkatan jumlah eritrosit dan hemoglobin.

\section{PEMBAHASAN}

Hasil penelitian ini sejalan dengan penelitian Artathi Eka Suryandari, Ossie Happina sari (2015), pemeberian $500 \mathrm{ml}$ jus buah bit dan Fe pada ibu hamil di Purwokwerto terbukti dapat meningkatkan kadar $\mathrm{Hb}$ lebih tinggi dibandingkan dengan pemebrian Fe saja.Hasil penelitian Stepana $\mathrm{W}(2017)$, yang mendapatkan hasil rata-rata kadar $\mathrm{Hb}$ ibu hamil pada kelompok eksperimen sebelum pemberian jus buah bit 9,50 gr/dL dan 9,18 g/dL pada kelompok 
kontrol. Setelah pemberian jus buah bit terjadi peningkatan kadar $\mathrm{Hb}$, dimana pada kelompok eksperimen kadar $\mathrm{Hb} 11,27 \mathrm{gr} / \mathrm{dL}$ dan pada kelompok kontrol 9,22 gr/dL hasil uji statistik mendapatkan adanya peningkatan yang bermakna dengan $\mathrm{P}<0,05$.

\section{KESIMPULAN}

Berdasarkan hasil pemeriksaan nilai indeks eritrosit sebelum dan sesudah mengonsumsi jus buah bit pada mahasiswa AAK 17 Agustus 1945 Semarang maka dapat diambil kesimpulan sebagai berikut :

a. Indek eritrosit sebelum mengonsumsi jus buah bit didapatkan rata-rata MCV $85 \mathrm{fl}$, dengan nilai minimum 79 fl dan nilai maksimum 90 fl. Rata-rata $\mathrm{MCH} 29$ pg, dengan nilai minimum 25 pg dan nilai maksimum 31 pg. Rata-rata MCHC $33 \%$, dengan nilai minimum $30 \%$ dan nilai maksimum $35 \%$.

b. Indek eritrosit sesudah mengonsumsi jus buah bit didapatkan rata-rata MCV $88 \mathrm{fl}$ dengan nilai minimum $75 \mathrm{fl}$ dan nilai maksimum 93 fl.. Rata-rata $\mathrm{MCH} 30$ pg dengan nilai minimum $27 \mathrm{pg}$ dan nilai maksimum 31 pg.. Rata-rata MCHC $34 \%$ dengan nilai minimum $31 \%$ dan nilai maksimum adalah $36 \%$.

c. Untuk Indek Eritrosit terjadi peningkatan nilai rata-rata $\mathrm{MCV}$ sebesar $3 \mathrm{fl}$ atau 3,5\%, nilai $\mathrm{MCH}$ meningkat 1 pg (3\%) dan nilai MCHC meningkat 1 point atau 3\%

d. Ada pengaruhyang signifikan $(\mathrm{P}<0,05)$ dimana kadar indeks eritrosit sesudah mengonsumsi jus buah bit lebih tinggi dibanding sebelum mengonsumsi jus jambu biji merah.

\section{SARAN}

Kepada peneliti selanjutnya
diharapkan agar berupaya lebih
mengembangkan dan memperdalam bahasan
tentang Pengaruh buat bit (beta vulgaris)
terhadap indek eritrosit pada remaja putri
dengan anemia dengan menggunakan desain penelitian yang berbeda.

\section{DAFTAR PUSTAKA}

Badriah Dewi L. (2014). Gizi Dalam Kesehatan Reproduksi. Cetakan kedua. Refika aditama.Bandung.

Departemen Kesehatan Republik Indonesia (2005).Direktorat Gizi Masyarakat dan Jendral Bina Kesehatan Masyarakat . Program Penanggulangan Anemia Gizi pada wanita Usia Subur. Jakarta. Depkes RI.

Direktur Bina Gizi. (RAPGM) (2014). Rencana Aksi Pembinaan Gizi Masyarakat (RAPGM) Tahun 2010-2014 [Internet]. Departemen Kesehatan Republik Indonesia; 2015. Available from: http://www.gizikia.depkes.go.id/ter bitan/rencana-aksi-pembinaangizi-

masyarakat-rapgm-tahun- 2010-2014/? print $=$ pdf

Gandasoebrata, R., 2010. Penuntun Laboratorium Klinik, Jakarta: Dian Rakyat.

Hallberg, B. Sandstrom and P.J. Agget L. (1994). Iron, zinc and other trace elements. In : Human Nutrition and Dietetics. Churchill Livingstone.

Helmi, A., Agustina \& Rizal, Z., 2013. Pengaruh Pemberian Jus Jambu Biji Merah (Psidiumguajava L.) Terhadap Jumlah Sel Eritrosit, Hemoglobin, Trombosit Dan Hematokrit Pada Mencit Putih. Jurnal Sains dan Teknologi Farmasi, 18(1), pp.43-48.

Indumathi T. Kannikaparameswari.K. (2012). Hematopoietic Study Of The Methanolic Root Extract Of Beta Vulgaris On Albino Rats-An In Vivo Study, Int J Pharm Bio Sci. 3(4):1005 - 1015

Kemenkes RI. (2013). Riset Kesehatan Dasar. Jakarta

Laksmi, M.K (2004). Sehat dengan Terapi Alami.Jakarta : PT Elex Media Kompuindo.

Mastuti., Yizhong Cai., Harold Corke. (2010). Identifikasi Pigmen Betasianin Pada Beberapa Jenis Inflorescence Celosia, 
Jurnal Biologi UGM, 669:667

Moreno, D.A., C. Garcia-Viguera, J.I. Gil and A. Gil-Izquierdo. (2008). Betasianins in the era of global agri-food science, technology and nutritional health. Phytocem. Rev. 7(2):261-280.

Price S. (2006). Konsep Klinis Prinsip Proses Penyakit. 6th ed. Huriawati Hartanto,Pita Wulansari DAM, editor. Jakarta: EGC; 913-991 $\mathrm{p}$

Puslitbangkes 2013. Riset Kesehatan Dasar 2013. Jakarta: Kementerian Kesehatan Republik Indonesia

Setiawan MAW, Nugroho EN., (2015), Ekstraksi Betasianin Dari Kulit Umbi Bit(Beta Vulgaris) Sebagai Pewarna Alami, J. AGRIC

Sianturi C. 2012. Pengaruh Vitamin C Pada Penyerapan Zat besi Non Heme.Medan : FMIPA UNM.

Sudoyo AW, Setiyohadi B, Alwi I, Simadibrata M, Setiati S.(2009)Buku Ajar Ilmu Penyakit Dalam Jilid II.edisi V. Jakarta: Interna Publishing

Suega, K. et al., (2007). Perbandingan Beberapa Metode Diagnosis Anemia Defesiensi Besi: Usaha Mencari Cara Diagnosis Yang Tepat Untuk Penggunaan Klinik. Jurnal Penyakit Dalam, 8(1).

Suhartati, R. \& Alwi, Y., (2015). Gambaran Indeks Eritrosit pada Pasien Tuberkulosis Paru. Jurnal Kesehatan Bakti Tunas Husada, 14(1).

Thankachan P, Walczyk T, Muthayya S, Kurpad AV, HurrellRF .(2008). Iron absorption in young Indian women : the interaction of iron status with the influence of tea and ascorbic acid. Am J ClinNutr.87 : 881-6 \{PubMed\}.

United States Department of Agriculture (2014)National Agricultural Statistics Service

.https://www.nass.usda.gov/Publications/ Ag_Statistics/2014/index.php

WHO.(2006). Sixty-fourth World Health Assembly, Youth and health risk.

Zhu L, Glahn RP, YeungCk, Miller DD. (2006). Iron uptake by Caco-2 cells from $\mathrm{NaFeEDTA}$ and FeSO4 : effects of ascorbic acid, $\mathrm{pH}$, and a Fe (ii) chelating agent. J Agric Food Chem. 54: 7924-8. $\{$ PubMed\} 